\title{
A Case with Anti TNF- $\alpha$ Induced Bullous Pemhigoid
}

\author{
Anti TNF- $\alpha$ Tedavisi Altında Gelişen Büllöz Pemfigoid Olgusu
}

\author{
Özlem Altındağ, Ali Aydeniz, Savaş Gürsoy \\ Gaziantep Üniversitesi, Fiziksel Tıp ve Rehabilitasyon Anabilim Dalı, Gaziantep, Turkey
}

\begin{abstract}
Tumor necrosis factor-alpha (TNF- $\alpha$ ) plays a crucial role in the development of autoimmune diseases, and anti-TNF- $\alpha$ agents are used in the treatment of this group of diseases. However, some adverse events such as various autoimmune diseases can occur with use of these agents. In this report, we present a female case who was diagnosed as bullous pemphigoid while receiving adalimumab for rheumatoid arthritis.
\end{abstract}

(Turk J Rheumatol 2010; 25: 214-6)

Key words: Bullous pemphigoid, anti tumor necrosis factoralpha, rheumatoid arthritis

Received: 03.10.2008

Accepted:19.01.2009

\section{Özet}

Otoimmün inflamatuvar hastalıkların etiyopatojenezinde TNF $\alpha$ 'nın önemli rolü olduğu ve tedavide anti-TNF- $\alpha$ ilaçların yıllardan beri kullanıldığı bilinmektedir. Bununla birlikte bu ilaçların kullanımı sırasında farklı otoimmün hastalıkların ortaya çıkması gibi istenmeyen sonuçlarla karșılașılabilmektedir. Bu yazıda romatoid artrit tanısıyla adalimumab kullandığı dönemde büllöz pemfigoid tablosu gelișen bir kadın hasta anlatıldı ve tartısıldı. (Turk J Rheumatol 2010; 25: 214-6)

Anahtar sözcükler: Büllöz pemfigoid, anti TNF-alfa, romatoid artrit

Alındığı Tarih: 03.10.2008 Kabul Tarihi: 19.01.2009

\section{Introduction}

Bullous pemphigoid is an autoimmune skin disease characterized by development of antibodies against mucous membranes and skin. Patients usually present with erythematous and itchy lesions progressing to large number of sensitive bullous lesions; it occurs more frequently in the elderly (1). Bullous pemphigoid may occur due to chronic autoimmune diseases or certain drugs. In this article, we report a case who developed bullous pemphigoid during anti-tumor necrosis factoralpha (TNF- $\alpha$ ) (adalimumab) treatment for rheumatoid arthritis.

\section{Case Presentation}

A 65-year-old female patient was admitted in our clinic with widespread erythema, especially on the knees, elbows and back, and bullous skin lesions concentrated on the lower abdominal region. The patient was diagnosed with rheumatoid arthritis 10 years before and had used different drugs. The patient's treatment was continued with prednisolone (4 mg/day), methotrexate
(15 mg/week), adalimumab (40 mg/2 weeks), folic acid (5 $\mathrm{mg} /$ day), and lansoprazole (30 mg/day) for one year. She described approximately two hours of morning stiffness. Physical examination of metacarpophalangeal (MCP) joints of both hands revealed swelling and increased heat. Both knees had crepitation and limitation of movement. Skin lesions suddenly appeared approximately one week before and increased within a few days. The widespread erythematous bullous lesions were present on her knees, wrists, elbows and back (Figures 1, 2 and 3). Arterial blood pressure was $120 / 70 \mathrm{mmHg}$ and pulse was $76 / \mathrm{min}$. Other system examinations were normal.

Laboratory findings were determined as: erythrocyte sedimentation rate: $60 \mathrm{~mm} / \mathrm{h}$, C-reactive protein: 27.1 $\mathrm{mg} / \mathrm{L}$, leukocytes: 8790/ $\mathrm{L}$, hemoglobin: $9.9 \mathrm{~g} / \mathrm{dl}$, rheumatoid factor: $210 \mathrm{IU} / \mathrm{ml}$, and platelets: $150.000 / \mu \mathrm{L}$. Ankylosis and narrowing of both wrist joints, erosions in MCP and proximal interphalangeal (PIP) joints and osteoporosis around joints, cystic changes, and joint space loss were seen on radiographic images.

After dermatological consultation, the patient's lesions were diagnosed as bullous pemphigoid. The patient had

Address for Correspondence: Dr. Özlem Altındağ, Gaziantep Üniversitesi, Fiziksel Tıp ve Rehabilitasyon Anabilim Dalı, Gaziantep, Turkey Phone: +903423606060/76280 E-mail: ozaltindag@yahoo.com 


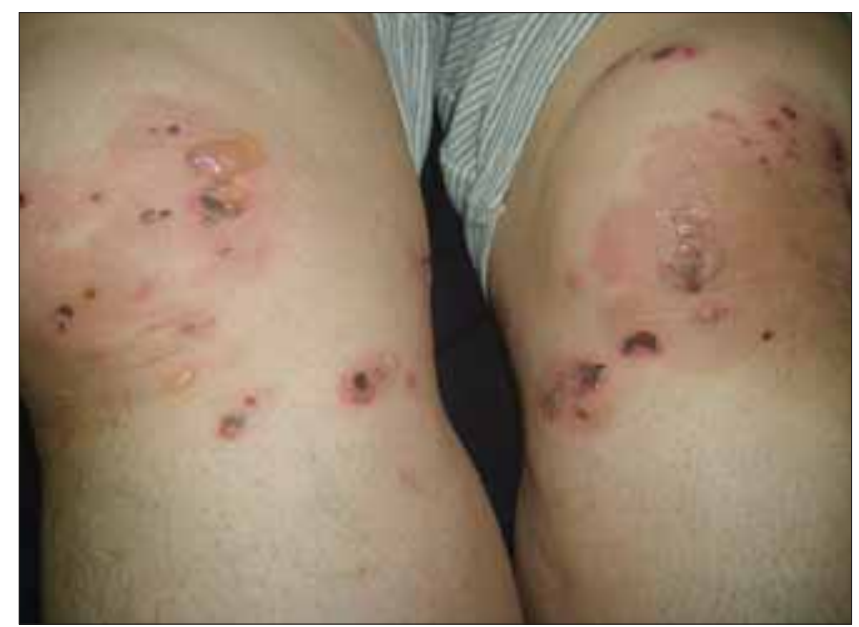

Figure 1. Erythematous bullous lesions on both knees

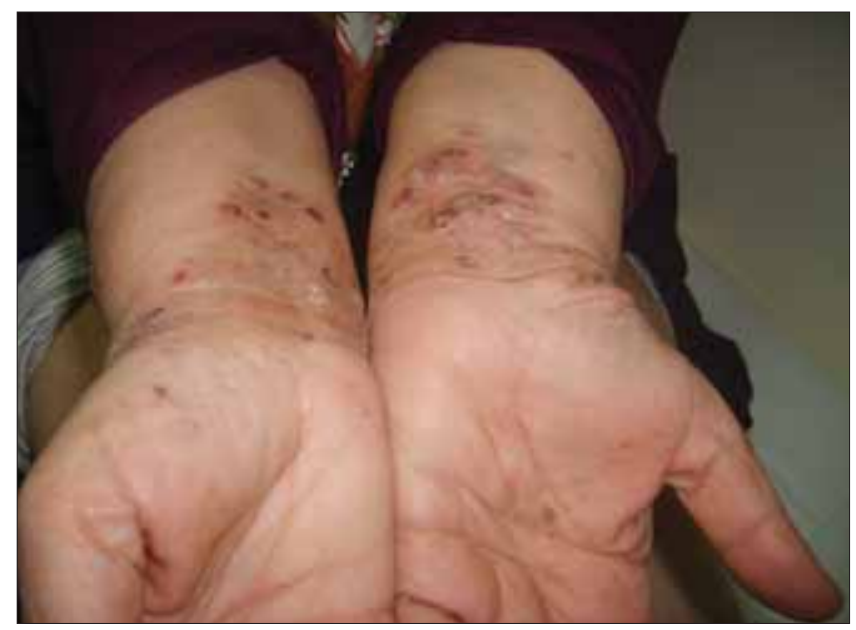

Figure 2. Erythematous bullous lesions on wrists

already stopped her treatment. Treatment was restarted with prednisolone $60 \mathrm{mg} /$ day and was continued by decreasing the prednisolone dose. The reduction in skin lesions was observed after two weeks of treatment.

\section{Discussion}

Autoimmune bullous diseases are a group of skin disorders presenting with erosions and bullous lesions and characterized by antibodies developed against cells found in skin and mucous membranes and against structural proteins lying between cells and matrix. The autoimmune bullous diseases are a group of skin disorders that include development of bullae and erosions. Bullous pemphigoid is the most common autoimmune bullous disease, and is usually seen in older ages $(1,2)$.

The lesions begin as an urticarial plaque on the body and extremities and are located mainly in the lower abdominal region, flexor side of extremities and on the inner side of the thigh; oral mucous membrane involvement is rare.

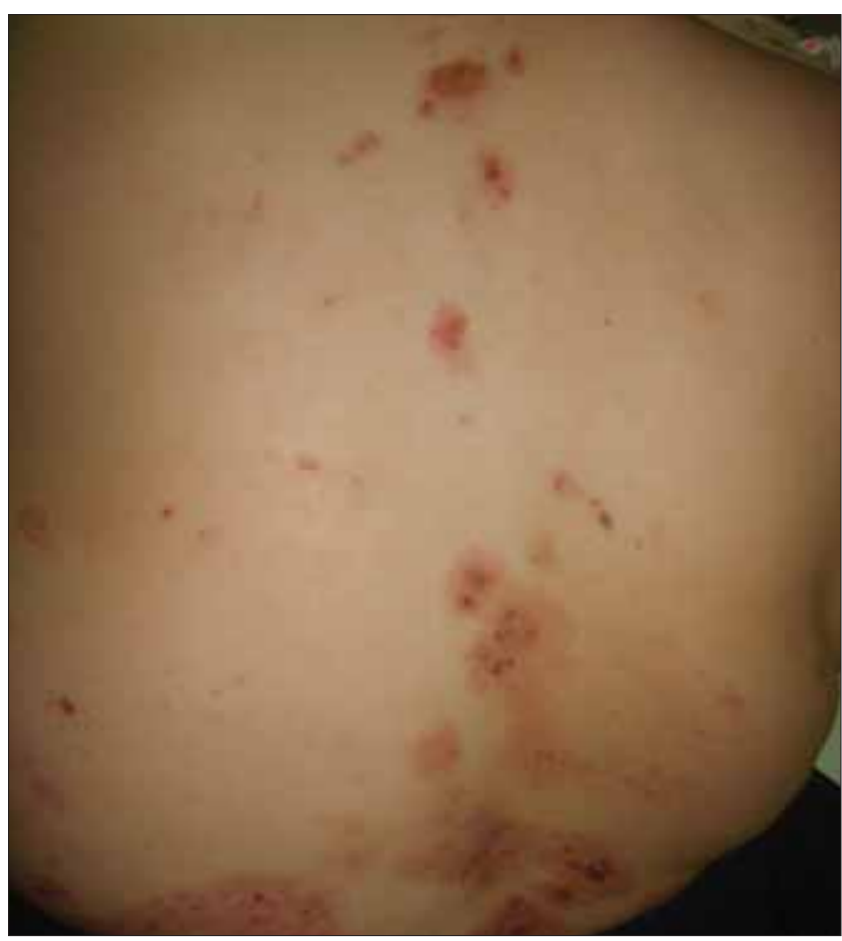

Figure 3. Erythematous bullous lesions on back

Bullous pemphigoid may be associated with other autoimmune diseases such as diabetes, pernicious anemia, rheumatoid arthritis, multiple sclerosis and chronic inflammatory diseases such as lichen planus, psoriasis vulgaris as well as some malignancies and drug use. It may occur due to penicillamine, ACE (angiotensin converting enzyme) inhibitors, B-adrenergic blockers, non-steroidal anti-inflammatory drugs, antibiotics, chloroquine, clonidine, nifedipine, antipsychotics, gabapentin, fluoxetine, omeprazole, or radiation (1).

Kijima et al. (3) identified a 68-year-old female patient who had used minocycline with a diagnosis of pharyngitis and developed bullous pemphigoid. Sudden-onset pemphigoid cases due to the use of penicillin, furosemide and simvastatin have also been reported (4-6).

TNF- $\alpha$ has played an important role in the pathogenesis of bullous skin disease in these patients, and high levels of serum TNF- $\alpha$ have been reported (7). Use of anti-TNF- $\alpha$ agents in treatment has brought about after the relationship between TNF- $\alpha$ and pemphigoid has been revealed. Anti-TNF- $\alpha$ drugs are used effectively for the treatment of rheumatoid arthritis as well and various adverse events including infection, injection reaction, allergic reaction, malignancy, demyelinating syndromes, congestive heart failure, bone marrow suppression and autoimmune diseases have been reported. Although antiTNF- $\alpha$ drugs are used successfully in the treatment of autoimmune diseases; several autoimmune diseases can develop as an adverse event. This paradox has been observed during the treatment of systemic lupus erythematosus, psoriasis, inflammatory bowel disease, and demyelinating diseases. 
We suggest that adalimumab treatment may have caused the pemphigoid condition in our patient. On the other hand, rituximab, an anti-CD20, which reduces $B$ lymphocyte CD20 surface antigen expression, is also used in the treatment of rheumatoid arthritis. Anti-TNF- $\alpha$ drugs have become widely used for treating systemic lupus erythematosus, multiple sclerosis and psoriasis, etc. Anti-TNF- $\alpha$ drugs may also lead to the emergence of these diseases.

Skin lesions of rheumatoid arthritis are seen as rheumatoid nodules, arteritis, palmar erythema, vasculitis, purpuric or necrotic skin lesions, livedo reticularis, and pyoderma gangrenosum (8). Bullous skin lesions due to anti-TNF- $\alpha$ drugs are not very common as a clinical picture. In the literature, only bullous pemphigoid due to infliximab treatment has been described (9). Adalimumabinduced pemphigoid cases have not been previously reported. We suggest that bullous pemphigoid is not just a skin disease due to rheumatoid arthritis, but also may develop during adalimumab treatment. Bullous pemphigoid development during the course of rheumatoid arthritis may be entirely coincidental.

How can we interpret two separate autoimmune diseases seen together in a patient with immune dysregulation? Should we use biological agents in the treatment of rheumatoid arthritis? Definite answers to these questions are difficult, but it should be kept in mind that bullous pemphigoid may occur in patients with rheumatoid arthritis and may be associated with antiTNF- $\alpha$ drugs.

\section{Conflict of interest}

No conflict of interest declared by the authors.

\section{References}

1. Patton T, Korman N. Role of methotrexate in the treatment of bullous pemphigoid in the elderly. Drug Aging 2008; 25 : 623-9.

2. Suárez-Fernández R, España-Alonso A, Herrero-González JE, Mascaró-Galy JM. [Practical management of the most common autoimmune bullous diseases]. Actas Dermosifiliogr 2008; 99: 441-55.

3. Kijima A, Inui S, Nakamura T, Itami S, Katayama I. Does druginduced hypersensitivity syndrome elicit bullous pemphigoid? Allergol Int 2008 Jun; 57: 181-2.

4. Wozniak K, Kowalewski C, Hashimoto T, Ishii N, GlinskaWielochowska M, Schwartz RA. Penicillin-induced anti-p200 pemphigoid: an unusual morphology. Acta Derm Venereol 2006; 86: 443-6.

5. Lee JJ, Downham TF 2nd. Furosemide-induced bullous pemphigoid: case report and review of literature. J Drugs Dermatol 2006; 5: 562-4.

6. Stoebner PE, Michot C, Ligeron C, Durand L, Meynadier J, Meunier L. [Simvastatin-induced lichen planus pemphigoides]. Ann Dermatol Venereol 2003; 130 (2 Pt 1): 187-90.

7. Asashima N, Fujimoto $M$, Watanabe $R$, Nakashima $H$, Yazawa N, Okochi $\mathrm{H}$, et al. Serum levels of BAFF are increased in bullous pemphigoid but not in pemphigus vulgaris. Br J Dermatol 2006; 155: 330-6.

8. Rashtak S, Pittelkow MR. Skin involvement in systemic autoimmune diseases. Curr Dir Autoimmun 2008; 10: 344-58.

9. Kent PD, Davis JM III, Davis MD, Matteson EL. Bullous skin lesions following infliximab infusion in a patient with rheumatoid arthritis. Arthritis Rheum 2002; 46: 2257-8.

10. Lee $H H$, Song $I H$, Friedrich $M$, Gauliard A, Detert J, Röwert J, et al. Cutaneous side-effects in patients with rheumatic diseases during application of tumour necrosis factor-alpha antagonists. J Dermatol 2007; 156: 486-91. 